\title{
TURNING THEM ON THE FIRST DAY OF CLASS
}

\author{
William F. Mugleston \\ Mountain View College
}

Teachers have heard all the tricks and techniques for arousing student interest that first challenging day of class. Rather than simply taking the roll, going over the syllabus, and giving an assignment, the instructor can ask students to tell something about themselves, form into small groups to have them get better acquainted, or make a special effort at learning student names. The instructor might tell something about herself or himself. Students can interview each other and report to the class. All of these are valuable first-day exercises.

History teachers face a special challenge, even on that first day of the semester. Because history is usually a required subject, at least on the survey or introductory level, we confront a "captive audience" often hostile about being there and convinced of the drudgery and uselessness of history.

Most historians realize the value of a humorous story or intriguing anecdote to make a point or to liven up a class, and many instructors assiduously collect such stories and "one liners." History, after all, is about people, and people are quirky, humorous, and unpredictable. Most beginning history students cannot imagine any connection between history and humor. Why not share them early on, a few of these anecdotes to show that history is about real people and indeed can be amusing and surprising as well as instructive. This technique can help pique student interest in what is to come in the semester.

Going through some of these the first day of class needn't take long. A single-sheet handout of 10 - 15 items is sufficient. Because some of them involve a bit of explaining, the teacher might simply promise to do so at the appropriate point in the course. Then be sure you do!

These examples are all culled from United States history and are in more or less chronological order. Instructors of any other areas of history could do the same. Answers are included here, but it is better not to put them on the handout sheet.

1. Who was Bjarni Herjolfson, and what did he discover?

(A Greenlander; perhaps the first European to discover North America, in 986 A.D. Students might be reminded that Columbus never set foot on North America.) 
2. How many English colonies were there in North America?

(A few knowledgeable students may answer 13; the correct number is closer to 27, if Canada and all the British West Indies possessions are included.)

3. What governor served only two days in office?

(A colonial governor of New York, who committed suicide)

4. Who got very concerned over naked necks, naked arms, and naked breasts?

(The Puritans, according to the minutes of a 1679 church council meeting)

5. Who was "Champagne Charlie"?

(Charles Townsend)

6. In the Declaration of Independence, Thomas Jefferson wrote, "All men are created equal." Who wrote, "All men and women are created equal"?

(The 1848 Seneca Falls Women's Rights Convention)

7. Who ran up an expense account of $\$ 449,000$ during the American Revolution?

(George Washington)

8. For eight years the United States did not have a president. When?

(Under the Articles of Confederation)

9. How did a pig help bring on War of 1812 ?

(This is a story, possibly apocryphal, of how a Rhode Island pig, eating in a neighbor's garden, led to a quarrel between neighbors which led in turn to the vote for war in the Senate. The author will be happy to share the details with interested readers.)

10. What newspaper reported details of life on the moon?

(The New York Sun, in an 1835 hoax.)

11. What President gave the longest inaugural address ever (one hour, 10 minutes), followed by the shortest term ever? 
12. Who mailed himself from slavery to freedom?

(Henry "Box" Brown, in 1848)

13. What president was elected to a six-year term?

(Jefferson Davis)

14. Who called the Gettysburg Address a "silly, flat, and dishwatery utterance"?

(The Chicago Times)

15. What president was seriously advised to postpone a Presidential Election?

(Abraham Lincoln, in 1864)

16. How many ten-year-olds served in the Civil War?

(At least 25)

17. How many former Civil War officers later served in the Egyptian Army? (Fifty)

18. Who were the first black U. S. Senators, from what state, and when? (Hiram Revels and Blanche K. Bruce, Mississippi, in the 1870s)

19. What president could write Latin with one hand and Greek with the other, simultaneously?

(James Garfield)

20. What President publicly admitted having fathered an illegitimate son?

(Grover Cleveland)

21. What does the Wizard of $\mathrm{Oz}$ have to do with American politics?

(Lyman Frank Baum, author of The Wonderful Wizard of $\mathrm{Oz}$, had a Populist background, and the book is full of Populist allusions. Because most students have seen the movie, this subject is worth a short lecture in class.)

22. What Asian jungle war involved tens of thousands of American troops? (not Vietnam)

(The Philippines insurrection) 
23. Who was born a slave but later in life had tea with the Queen of England? (Booker T. Washington)

24. What President was described as a "madman" and "clearly insane"? (Theodore Roosevelt)

25. Who was Lydia Pinkham, and why did so many women admire her? (The cult surrounding Lydia Pinkham's Vegetable Compound)

26. What presidential candidate was shot in the chest and immediately thereafter gave a one-hour speech?

(Theodore Roosevelt, in 1912)

27. In what state was it once illegal to speak German in public? (Iowa, during World War I)

28. What French Premier offered American soldiers the use of French brothels? (Georges Clemenceau, during World War I)

29. What presidential candidate received almost a million votes while in prison? (Eugene V. Debs, in 1920)

30. What president was described as "not a bad man--just a slob"? (Warren Harding, by Alice Roosevelt Longworth)

31. What well-known American said, when introduced to President Calvin Coolidge, "Pardon me, I didn't catch the name."?

(Will Rogers--who else?)

32. What First Lady joined a union?

(Eleanor Roosevelt; the American Newspaper Guild)

33. What American woman won the Nobel Peace Prize in 1931? (Jane Addams) 
34. What does the "S" in Harry S Truman stand for? (Nothing)

35. What black American won the Nobel Peace Prize in 1950 ?

(Ralph J. Bunche. While all students have heard of Martin Luther King, few if any will know of Bunche.)

36. Which President's Cabinet was known as "eight millionaires and a plumber"?

(Dwight Eisenhower's first Cabinet. Secretary of Labor Martin Durkin was a union official; most of the others were corporation executives.)

37. What U. S. Senator was known among his colleagues as the "Pepsi-Cola Kid"? (Joseph R. McCarthy)

38. What world leader wanted to visit Disneyland, but wasn't allowed to?

(Nikita Khrushchev, for security reasons)

39. How will a knowledge of baseball help you predict who the next president will be?

(Margolis's Law: In a presidential election year, if the National League team wins the World Series, the Democratic candidate will win in November; if the American League team wins, the Republicans will win. I have heard there is a similar correlation with the Super Bowl results.)

Finally, there is a serious side to all this. Many of these items touch on substantial matters such as women's history, black history, and politics, and can serve as springboards to fruitful class discussions. 